\author{
佐藤彰**中川 龍一**.吉松 史朗** \\ 福沢章**. 尾崎 太头
}

\title{
Effect of the Kind of Iron Oxide in Reduced Iron Pellets on the Melting rate into Iron Melt
}

Akira SAto, Ryuichi Nakagawa, Shiro Yoshimatsu

Akira Fukuzawa, and Tsuyoshi Ozaki

\begin{abstract}
Synopsis:
The melting rate into iron melt of partly reduced iron pellets made from pure iron powder and iron oxide powder by pressing has been measured. The effects of the kind of iron oxides in pellets and the weight of pellets on the melting rate of pellets have been investgated. The following results are obtained:

(1) $\mathrm{FeO}, \mathrm{Fe}_{3} \mathrm{O}_{4}$ and $\mathrm{Fe}_{2} \mathrm{O}_{3}$ were identified in low reduction pellets produced commercially while only $\mathrm{FeO}$ was found in high reduction pellets.

(2) The difference of melting rate among the pellets containing different iron oxides was small for the constant content of oxygen in reduced iron pellts.

(3) The apparent activation energy of melting into iron melt of pellets containing $\mathrm{FeO}$ was 33 $\mathrm{kcal} / \mathrm{mol}$ which was the same as that of those containing $\mathrm{Fe}_{2} \mathrm{O}_{3}$, while that of those containing $\mathrm{Fe}_{3} \mathrm{O}_{4}$ was $21 \mathrm{kcal} / \mathrm{mol}$.
\end{abstract}

(4) The maximum melting rate of pellets containing iron oxides was obtained at the range of 2.5 $\sim 3.5 \% \mathrm{C}$ in iron melt.

(5) The melting rate of pellets into iron melt increased with increasing the weight of pellets.

\section{1. 緒言}

還元鉄，半還元鉱を原料とする連続製鉄プロセスの開 発研究において, これらのペレットの溶鉄中への溶解挙 動が極めて重要であると考えられた，そこで，鉄紛，酸 化鉄紛および添加剂からペレットを圧縮成形し，ペレッ ト中の脈石成分の組成と量, 未還元酸素としての第二酸 化鉄量，溶鉄の炭素量と温度，溶鉄上の溶澾が溶解速度 におよぽす影響を調べた結果，これらの諸因子が溶解速 度に大きい影響を打よぼすことを確認した1) 3)。一方， 実際に工業的に製造されたペレットでは，含有される酸 化鉄の種類が還元率によつて相違すること, 圧縮成形し たペレットが 70 あるいは $50 \mathrm{~g}$ であるのに比べて重量 が約 $15 \mathrm{~g}$ と小さいことなどが溶解速度に大きい影響を
およぼすのではないかといら議論があつた。ここでは， ペレットに含有される酸化鉄の種類打よびペレットの重 量が溶解速度におよぼす影響について検討した結果，い ずれも大きい影響を执よぼさないことがわかつたので報 告する.

\section{2. 実 験 方 法}

工業的に製造された還元鉄ペレット中の酸化鉄の種類 を紛末試料のX線回折によつて同定した. ターダットに Co を用い， $2 \theta$ について $10^{\circ}$ から $105^{\circ}$ まで $2^{\circ} / \mathrm{min}$ で走査した. ペレットの製造に用いたへガネス鉄紛, $\mathrm{Fe}_{2} \mathrm{O}_{3}$ 紛 (特級試薬), $\mathrm{Fe}_{3} \mathrm{O}_{4}$ 紛 (一級相当試薬) および $\mathrm{FeO}$ 紛（一級相当試薬の $\mathrm{Fe}_{2} \mathrm{O}_{3}$ を還元したもので 93.8 $\% \mathrm{FeO}$ )を標準試薬として使用し，ASTM カードの補

* 昭和 54 年 4 月本会講演大会にて発表 昭和 54 年 8 月 6 日受付 (Received Aug. 6, 1979)

** 金属材料技術研究所工博 (National Research Institute for Metals, 2-3-12 Nakameguro Meguro-ku 153)

*** 金属材料技術研究所 (National Research Institute for Metals) 
助とした. シャフト炉による脈石成分含有量の少ない $96 \%$ 金属化率のペレット,脈石成分の多い $55 \%$ 金属化 率のペレット拉よびロータリーキルンによる脈石成分の 多い $84 \%$ 金属化率のペレットの大，中，小の粒度のも のについてそれぞれX線回折を行つた。

還元鉄ペレットの溶解に要する時間の測定は $3 \mathrm{~kg}$ 雾 囲気溶解タンマン炉を主とする装置を用いて行つた ${ }^{233)}$. 炉の温度は土 $5^{\circ} \mathrm{C}$ 亿制御され，発生 $\mathrm{CO}$ ガス量は積算 型湿式実験用ガスィーターで測定した2)3).

内径 $55 \mathrm{~mm}$ ，高さ $190 \mathrm{~mm}$ の黒鉛あるいはアルミナ るつぼを，それぞれ，炭素飽和溶鉄あるいは飽和以外の 炭素量の溶鉄の実験に使用した.

還元鉄ペレットを断面積 $7 \mathrm{~cm}^{2}$ のダイスとポンチを用 い, $60 \mathrm{t}$ 油圧プレスによつて前記の鉄紛と酸化鉄紛から 円筒形に压縮成形した ${ }^{1)}$ ）. 成形圧力は $4 \mathrm{t} / \mathrm{cm}^{2}$, 酸化鉄 含有量はペレット中の酸素含有量が主に $3.0,6.0,12.0$ wt％となる量とした. 圧縮成形後のペレットの重さを 直視天称で，高さをマイクロメーターで測定して比重を 計算した.

ペレットの溶鉄中への溶解速度におよぼす溶涬の影響 を $100 \mathrm{~g}$ の塩基度 1 のスラブ $\left(43.5 \% \mathrm{CaO}-44.1 \% \mathrm{SiO}_{2}\right.$ $12.4 \% \mathrm{Al}_{2} \mathrm{O}_{3}$ ) を用いて調べた ${ }^{3)}$.

実験手順は以下のよらである， $\mathrm{N}_{2}$ ガスを流通しなが ら溶解された溶鉄の表面を清浄にし，㩭拌した後分析試 料を採取してのぞき空を閉じる．密閉後 $5 \mathrm{~min}$ から 2 $\min$ 間 $\mathrm{N}_{2}$ ガス流量を $30 \mathrm{~s}$ ごとに記録し, あらかじめ炉 の上部に装入されていた還元鉄ペレットを溶鉄上に落下 させる. ペレットの落下時を起点として $5 \mathrm{~s}$ ごとに目盛 を記録する.目盛の記録は肉眼でペレットの溶解が終了 したのを確認してからさらに $2 \mathrm{~min}$ 間続ける. 各条件に ついて複数回の実験を行つて再現性を確認した.

$\mathrm{CO}$ ガス発生量を時間を横軸とするグラフに表示し， $\mathrm{CO}$ ガス発生量が零となるまでの時間を溶解に要する時 間とした．酸化鉄を含有しないペレットの溶解に要する 時間はのぞき空からの観察によつて決定した。 また，溶 解速度 $v(\mathrm{~g} / \mathrm{s})$ はペレットの重量を溶解に要する時間 で除したものとした。

\section{3. 実 験 結 果}

Table 1 は工業的に製造された還元鉄ペレットの粉末 試料のX線回折の結果を示す. 鉄および各酸化鉄の強度 の順番はASTM カード㧍よび試薬の回折線強度から決 定した．試料間の強度の比較はできないが，脈石成分含 有量の少ないシャフト炉による高還元率ペレット（No. 1)では $\mathrm{Fe}$ と $\mathrm{FeO}$ の存在が認められる。眽石成分の
Table 1. Intensity of X-ray diffraction of powdered pellets manufactured commercially.

\begin{tabular}{l|c|r|r|r|r}
\hline \multirow{2}{*}{$2 \theta^{*}$} & \multirow{2}{*}{ Standard** } & \multicolumn{4}{|c}{ Pellet*** } \\
\cline { 3 - 6 } & & No. 1 & No. 2 & No. 3 & No. 4 \\
\hline 99.7 & I -2 & 95 & 40 & 44 & 96 \\
77.3 & I -3 & 56 & 23 & 23 & 58 \\
74.2 & M-3 & 1 & 7 & 32 & 38 \\
72.0 & W-3 & 9 & - & 22 & 32 \\
67.3 & M-5 & - & -- & 20 & 17 \\
63.5 & H-3 & - & - & - & 28 \\
61.5 & C-2 & - & 6 & - & 12 \\
57.9 & H-5 & 11 & - & - & 26 \\
52.4 & I-1 & 300 & 250 & 250 & 300 \\
50.4 & M-4 & 14 & - & 26 & 30 \\
49.1 & W-1 & 17 & - & 71 & 56 \\
42.2 & W-2 & 15 & - & 39 & 50 \\
41.4 & M-1, H-2 & - & 15 & 114 & 114 \\
38.5 & H-1 & - & - & - & 76 \\
36.6 & C-1 & - & 23 & 8 & 22 \\
35.0 & M-2 & - & 6 & 21 & 47 \\
33.5 & G-3 & - & 9 & - & - \\
27.9 & H-4 & - & - & - & 30 \\
\hline
\end{tabular}

$*: \lambda=1.79021 \AA$

** : I : Pure iron, W : Wüstite, $\mathrm{H}$ : Hematite, $\mathrm{M}$ : Magnetite. C : Calcium aluminum silicate; Numbers show sequence of the intensity.

***: No. 1 : Reduced in shaft furnace with $96 \%$ metallization, $5.7-9.5 \mathrm{~mm} \phi$. No. 2 : Reduced in rotary kiln with $84 \%$ metallization, about $14 \mathrm{~mm} \phi$. No. 3 and No. 4 : Reduced in shaft furnace with $55 \%$ metallization, under $2.8 \mathrm{~mm} \phi$ and 5.7-9.5 $\mathrm{mm} \phi$.

多いロータリーキルンによる高還元率ペレット (No.2) では $\mathrm{Fe}$ と $\mathrm{Fe}_{3} \mathrm{O}_{4}$ が認められる. 脈石成分の多いシャ フト炉による低還元率ペレットの小粒径のもの (No.3) では $\mathrm{Fe}, \mathrm{FeO}, \mathrm{Fe}_{3} \mathrm{O}_{4}$ の存在が認められ, 大粒径のも の (No.4) では $\mathrm{Fe}, \mathrm{FeO}, \mathrm{Fe}_{3} \mathrm{O}_{4}, \mathrm{Fe}_{2} \mathrm{O}_{3}$ のすべてが 存在することが確認された.

還元鉄ペレットの比重におよぽす酸化鉄の種類と量の 影響を同一酸素含有量で比較すると，酸素量が $5 \mathrm{wt} \%$ 以上では $\mathrm{FeO}, \mathrm{Fe}_{3} \mathrm{O}_{4},, \mathrm{Fe}_{2} \mathrm{O}_{3}$ の高還元率の順に高比 重であることがわかつた。

Fig. 1 は還元鉄ペレットの $1520^{\circ} \mathrm{C}$ 炭素飽和溶鉄中 への溶解に要する時間におよぼすペレット中の酸化鉄の 種類と量の影響を示す．溶解に要する時間は $0.5-1.5$ $\%$ の酸素量で最短となり, $5 \%$ 以上では酸素量の增加と ともに増加している，溶解に要する時間におよぼす酸 化鉄の種類の影響は小さいが，5\% 以上の酸素量では $\mathrm{Fe}_{3} \mathrm{O}_{4}, \mathrm{Fe}_{2} \mathrm{O}_{3}, \mathrm{FeO}$ の順に溶解に要する時間は短いこ とが示されている.

Fig. 2 は溶鉄上に $100 \mathrm{~g}$ の塩基度 1 の溶涬があると き，還元鉄ペレットの $1520^{\circ} \mathrm{C}$ 炭素飽和溶鉄中への溶 解に要する時間におよぼすぺレット中の酸化鉄の種類と 量の影響を示す。ペレットの重量は $50 \mathrm{~g}$ であり, 溶解 


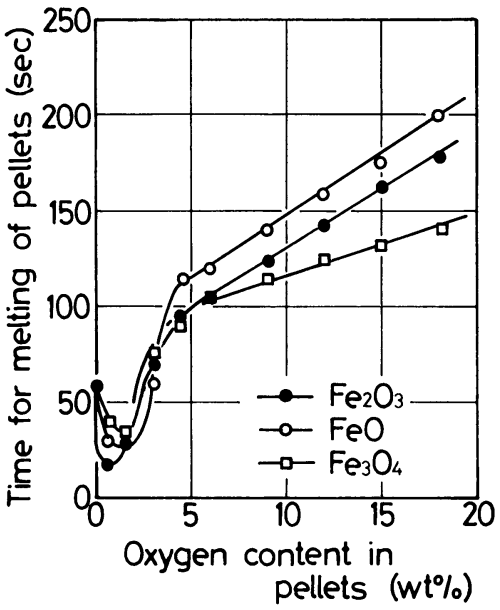

Fig. 1. Dependence of the time for melting of pellets on the content and the kind of iron oxides at $1520^{\circ} \mathrm{C}$.

に要する時閒は浴涬に溶け込んだ酸化鉄の還元反応を無 視して求めた3)。溶解に要する時間におよぼす酸化鉄の 種類の影響はほとんど認められない，溶解に要する時間 は酸素量の増加とともに増加し，溶㳯がないときに比べ て長いことが示されている。

Fig.3 は (a) $\mathrm{FeO}$ および (b) $\mathrm{Fe}_{3} \mathrm{O}_{4}$ を含有する還元 鉄ベレットの炭素館和溶鉄中への溶解に要する時間にお よぼす溶鉄温度の影響を示す， $\mathrm{FeO}$ 量が多く,温度が低 いときに溶解に要する時間は著しく長い. $13.5 \% \mathrm{FeO}$ の ベレットの溶解に要する時間は $1520-1620^{\circ} \mathrm{C}$ で汇と んど同じであることを，ペレットの製造からの再実験に

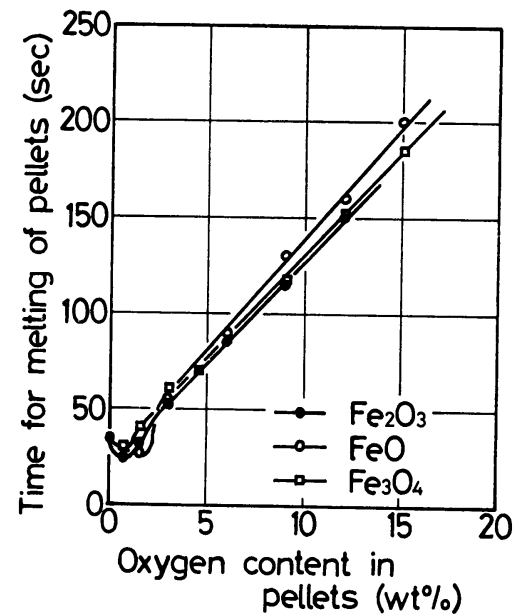

Fig. 2. Effect of the content and the kind of iron oxides in pellets on the time for melting into carbon saturated iron melt at $1520^{\circ} \mathrm{C}$ with the molten slag of unit basicity weighing $100 \mathrm{~g}$.

よつて確認した。 また， $21.8 \% \mathrm{Fe}_{3} \mathrm{O}_{4}$ のペレットの溶解 に要する時間が 1320 と $1370^{\circ} \mathrm{C}$ で $43.5 \% \mathrm{Fe}_{3} \mathrm{O}_{4}$ の ものより長いことも再実験によつて確かめた。 $21.8 \%$ $\mathrm{Fe}_{3} \mathrm{O}_{4}$ のペレットはこれらの温度で溶解が進行して小さ くなると，しばらく溶鉄と反応しないで浮いているため に溶解に要する時間が長くなることが観察された.

Fig.4 は (a) $\mathrm{FeO}$ および (b ) $\mathrm{Fe}_{3} \mathrm{O}_{4}$ を含有する還元 鉄ペレットの $1520^{\circ} \mathrm{C}$ 溶鉄中への溶解に要する時間に およぼす溶鉄の炭素量の影響を示す。ペレットの重量は

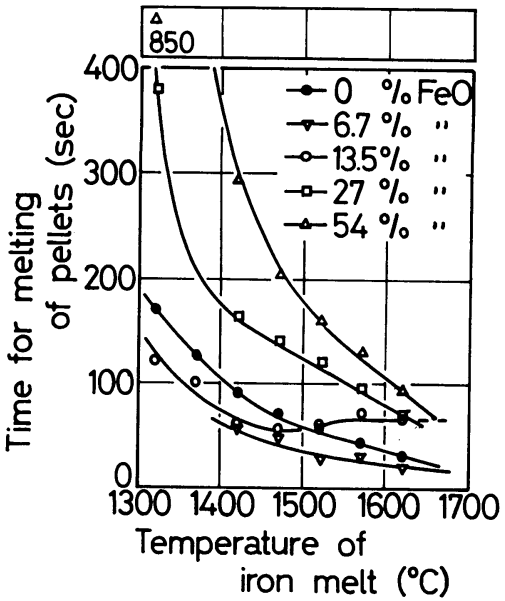

(a)

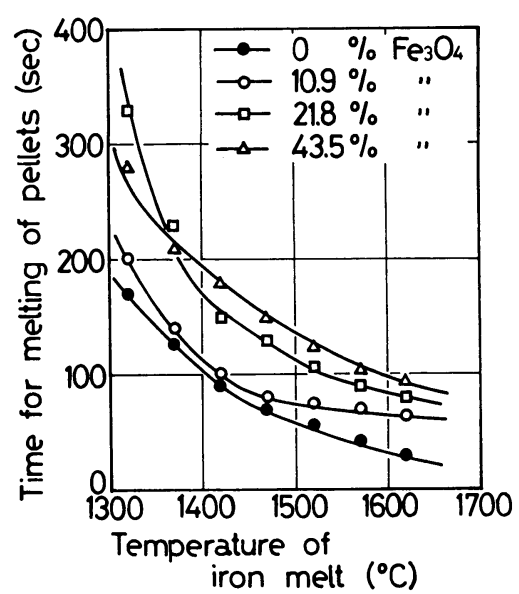

(b)

Fig. 3. Dependence of the time for melting of pellets containing (a) $\mathrm{FeO}$ and (b) $\mathrm{Fe}_{3} \mathrm{O}_{4}$ into iron melt saturated with carbon on temperature. 


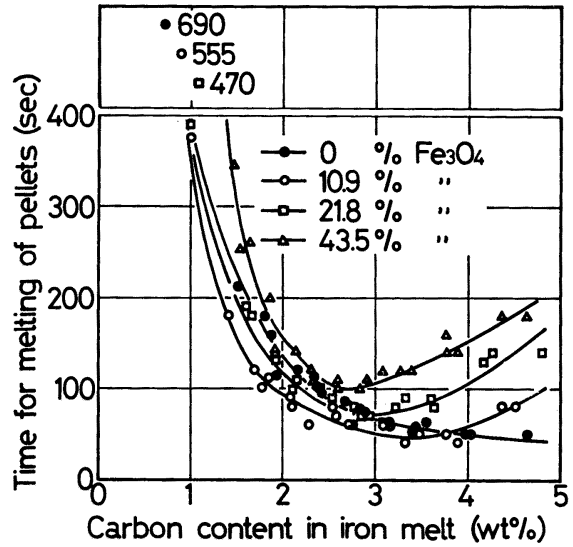

(a)

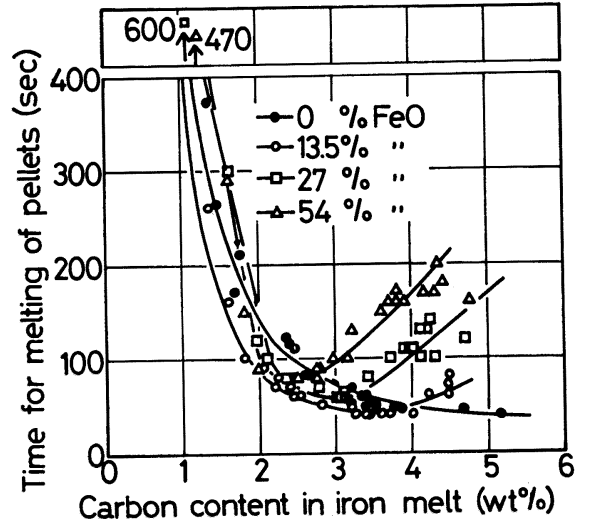

(b)

Fig. 4. Dependence of the time for melting of pellets containing (a) $\mathrm{FeO}$ and (b) $\mathrm{Fe}_{3} \mathrm{O}_{4}$ on the carbon content in iron melt.

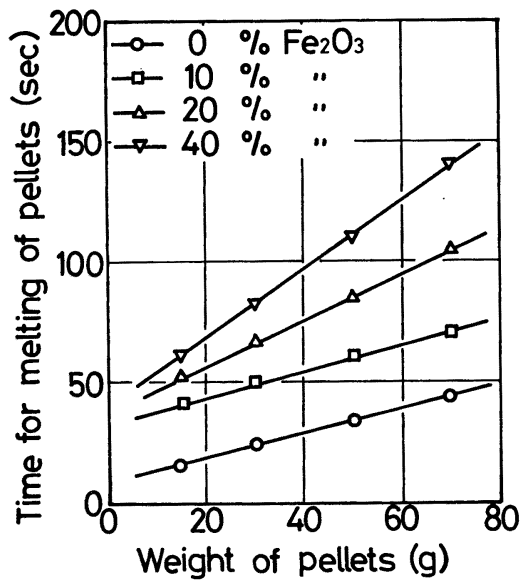

Fig. 5. Dependence of the time for melting of pellets on the weight and the content of $\mathrm{Fe}_{2} \mathrm{O}_{3}$.

$50 \mathrm{~g}$ であつた. $\mathrm{Fe}_{2} \mathrm{O}_{3}$ を含有するペレットの場合と同様 に, $\mathrm{FeO}$ あるいは $\mathrm{Fe}_{3} \mathrm{O}_{4}$ を含有するペレットの溶解に 要する時間は 2.5-3.5\% Cに执いて最短となり, $1.5 \% \mathrm{C}$ 以下では著しく長いことが示された.

Fig.5 は還元鉄ペレットの $1520^{\circ} \mathrm{C}$ 炭素飽和溶鉄 中への溶解に要する時間におよぼすぺレットの重量と $\mathrm{Fe}_{2} \mathrm{O}_{3}$ 量の影響を示す. 各 $\mathrm{Fe}_{2} \mathrm{O}_{3}$ 含有量のペレットの溶 解に要する時間は, ペレットの重量増加とほぼ直線的に 増加した. また，酸化鉄の種類の相違による溶解に要す る時間の相違は高々 $15 \%$ であつた.

\section{4. 考察}

低還元率還元鉄ペレットの溶鉄中への溶解過程は，1)
溶鉄からペレットへの熱移動，2) 溶鉄中炭素の溶解界面 への移動，3)ペレット中鉄の溶鉄への移動，4）ペレット 中の未還元酸化鉄の還元反応が主なものと考えられる4) ６). 未還元酸化鉄として $\mathrm{Fe}_{2} \mathrm{O}_{3}$ を含有するペレット を用いた実験において，溶解過程の律速段階は $\mathrm{Fe}_{2} \mathrm{O}_{3}$ を 含有しないものでは熱移動, $\mathrm{Fe}_{2} \mathrm{O}_{3}$ を含有するものでは 還元反応であると推定された22.

Fig.6は(a) $\mathrm{FeO}$ および (b) $\mathrm{Fe}_{3} \mathrm{O}_{4}$ を含有する還元 鉄ペレットの溶解速度の対数と温度の逆数との関係を示 す. $\mathrm{Fe}_{2} \mathrm{O}_{3}$ を含有するペレットの溶解速度の温度依存性 は酸化鉄を含有しないペレットのものと同一で，みかけ の活性化エネルギは $33 \mathrm{kcal} / \mathrm{mol}$ が得られた2). $13.5 \%$ $\mathrm{FeO}$ ペレットの高温側と $54 \% \mathrm{FeO}$ ペレットの低温側 を除いて, $\mathrm{FeO}$ を含有するペレットの溶解速度の温度依 存性は酸化鉄を含有しないペレットのものとほぼ同一 で，みかけの活性化ェネルギも $33 \mathrm{kcal} / \mathrm{mol}$ であるこ とが示されている.これに対して，10.9\% $\mathrm{Fe}_{3} \mathrm{O}_{4}$ ペレッ 卜の低温側での溶解速度の温度依存性は酸化鉄を含有し ないペレットのものとほぼ同一であるが，21.8\% $\mathrm{Fe}_{3} \mathrm{O}_{4}$ の高温側および $43.5 \% \mathrm{Fe}_{3} \mathrm{O}_{4}$ ペレットの溶解速度の温 度依存性は酸化鉄を含有しないペレットのものより低 く，みかけの活性化ェネルギは $21 \mathrm{kcal} / \mathrm{mol}$ であるこ とが示された. $\mathrm{Fe}_{3} \mathrm{O}_{4}$ を含有するペレットの溶解のみか けの活性化エネルギが, $\mathrm{FeO}$ を含有するペレットのもの より小さいことは, DANCY ${ }^{4)}$ の結果と一致していると考 えられる。

のぞき空からの観察によつて還元鉄ペレット中の酸化 鉄は固体状態で溶鉄中の炭素と反応することが確認され ているので，ペレットと溶鉄との接触面積が溶解速度に 


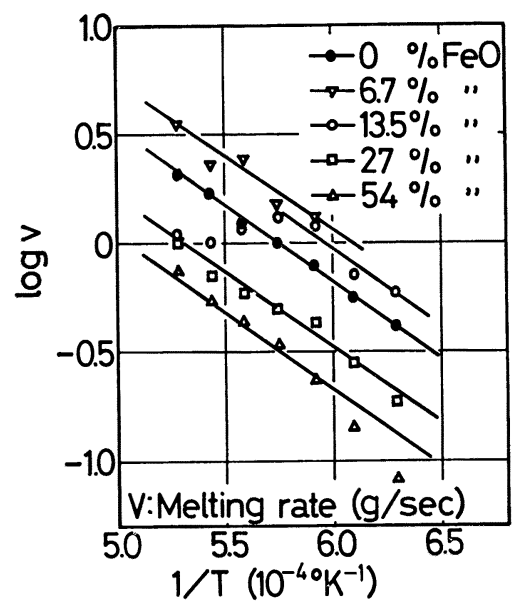

(a)

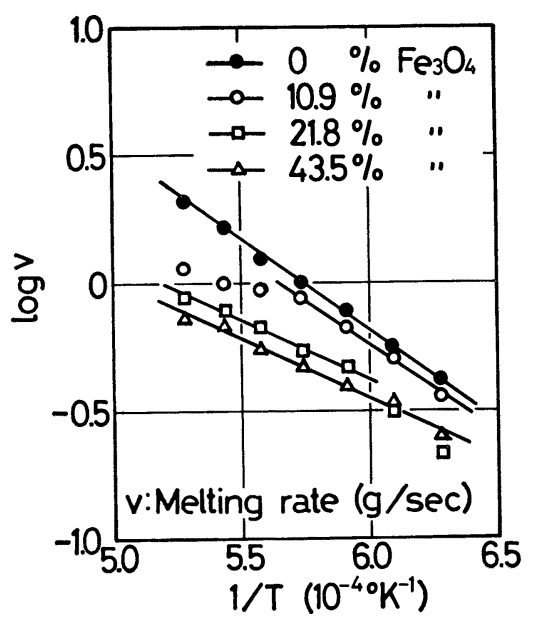

(b)

Fig. 6. Relation between $\log \mathrm{v}$ and $1 / T$ of pellets containing (a) $\mathrm{FeO}$ and (b) $\mathrm{Fe}_{3} \mathrm{O}_{4}$.

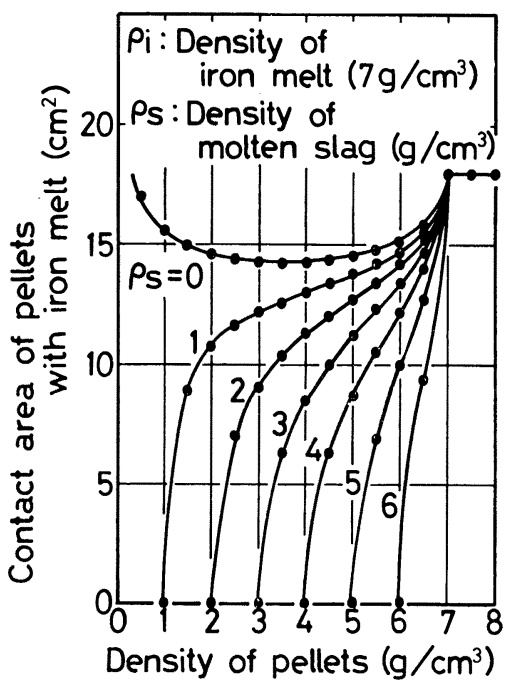

Fig. 7. Relation among the contact area of pellets weighing $50 \mathrm{~g}$ with iron melt, the density of pellets and the density of molten slag when the density of iron melt is $7 \mathrm{~g} / \mathrm{cm}^{3}$.

大きい影響を打よぼすと考党られた。円筒形のペレット が溶解するとき球形に近づくことが観察されたので，ぺ レットの形を球とし, ペレットの比重が溶涬あるいは溶 鉄の比重之同一のときはペレットは底まで沈及込むとし て，ペレットと溶鉄との接触面積を計算した．Fig.7 は $50 \mathrm{~g}$ のペレットの溶鉄との接触面積, ペレットの比重抏 よび溶澾の比重との関係を示す. 溶鉄の比重は $7 \mathrm{~g} / \mathrm{cm}^{3}$ とした。この図から溶㳯がないとき $\left(\rho_{\mathrm{s}}=0\right)$ には, 酸 化鉄の種類の相違によるペレットの比重の相違が接触面
積に㧍よぼす影響は極めて小さいことがわかる。また， 比重が $2.6 \mathrm{~g} / \mathrm{cm}^{3}$ の溶涬 ${ }^{8}$ があるとき, $\mathrm{FeO}$ を含有する ペレットの接触面積は $\mathrm{Fe}_{2} \mathrm{O}_{3}$ を含有するペレットの接 触面積上り最大約 $18 \%$ 大きいが，溶解に要する時間が $\mathrm{FeO}$ を含するペレットの方が長いので, 溶涬があるとき には酸化鉄の種類が溶解に要する時間に汪とんど影響し ないといら結果が得られたものと考えられる.

還元鉄ペレットの溶解に要する熱量は，同一酸素含 有量で比較すると, $\mathrm{Fe}_{2} \mathrm{O}_{3}, \mathrm{Fe}_{3} \mathrm{O}_{4}, \mathrm{FeO}$ の順に大きい が，Fig.1 の結果から溶解に要する熱量は溶解速度に大 きい影響を拈よぼさないことがわかる。

Fig.8 は (a) $\mathrm{FeO}$ 拈よび (b) $\mathrm{Fe}_{3} \mathrm{O}_{4}$ を含有する還元 鉄ペレットの溶解速度の対数と溶鉄中炭素の重量パー七 ントの対数との関係を示す. 最大溶解速度を示す炭素量 以下では, 溶解速度は炭素量の, $\mathrm{FeO}$ を含有するペレッ 卜では $\mathrm{Fe}_{2} \mathrm{O}_{3}$ を含有するものと同じく約 2.4 乗, $\mathrm{Fe}_{3} \mathrm{O}_{4}$ を含有するものでは約 1.9 乗に比例することが示され た．酸化鉄を含有するペレットの溶鉄中への溶解速度が 2.5-3.5\% C の炭素量に扔いて最大值を示すことは，溶 鉄の比重，粘性，表面張力扣よびペレットとの濡れ性な どが $\mathrm{CO}$ ガスの発生に拉よ济す影響も考虑すべきと考 えられるが，詳細なデータが見当たらない8)。しかしな がら，高炭素溶鉄ゆの酸素の活量係数が約 $2 \% \mathrm{C}$ に打い て最小值を示していること帛から，反応速度が最大とな つたと推察される.

Fig.9 は還元鉄ペレットの溶解速度に拉よぼすぺレッ 卜の重量と $\mathrm{Fe}_{2} \mathrm{O}_{3}$ 量の影響を示す. 溶解速度とペレッ 卜重量とはわずか上に凸な曲線関係にあり，重い方が溶 


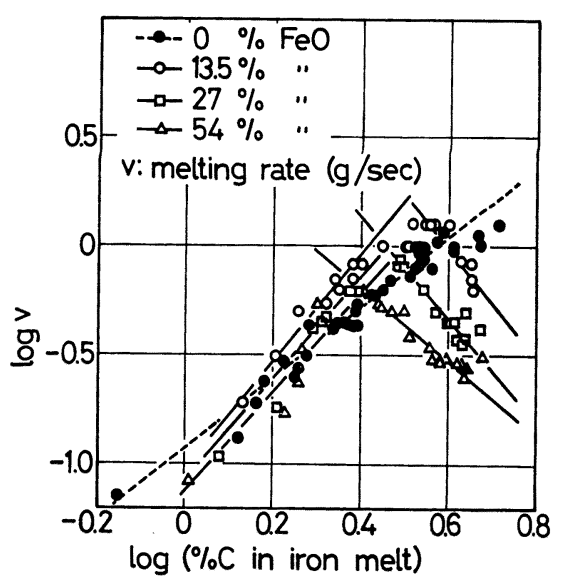

(a)

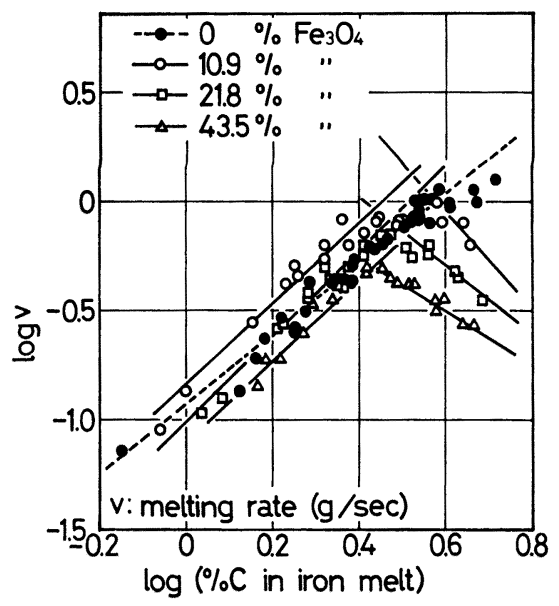

(b)

Fig. 8. Relation between $\log \mathrm{v}$ and $\log (\% \mathrm{C}$ in iron melt $)$ of pellets containing (a) $\mathrm{FeO}$ and (b) $\mathrm{Fe}_{3} \mathrm{O}_{4}$.

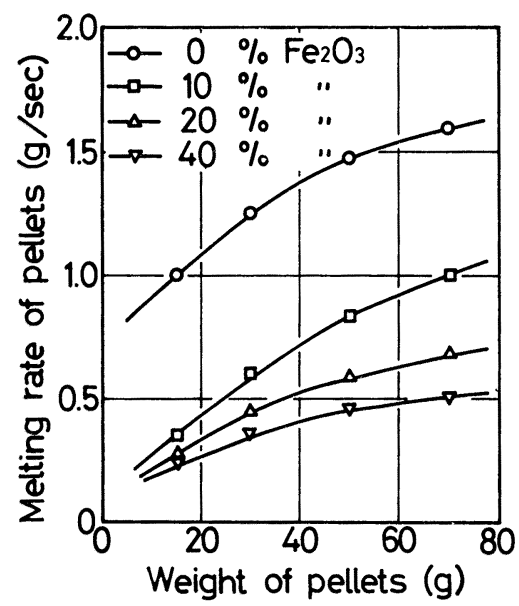

Fig. 9. Dependence of the melting rate of pellets on the weight and the content of $\mathrm{Fe}_{2} \mathrm{O}_{3}$.

解速度が少し速い。ペレットの溶解速度と重量との関係 に拉よぼす酸化鉄の種類の影響も小さいことがわかつ

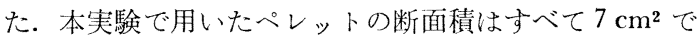
あり, 重量によつて高さが変化し，軽いときには円板状 であるが，この形状の影響も大きくないと音える。

\section{5. 結言}

鉄粉之酸化鉄粉から円筒形の還元鉄ヘレットを生縮成 形し，ペレットの溶鉄中への溶解速度に打よぼす酸化鉄 の種類とペレット重量の影響について検討した．得られ た結果は以下のようである。

1) 工業的に製造された還元鉄べレット中の未還元酸
化鉄として，高還元率のものでは $\mathrm{FeO}$, 低還元率のもの では $\mathrm{FeO}, \mathrm{Fe}_{3} \mathrm{O}_{4}, \mathrm{Fe}_{2} \mathrm{O}_{3}$ が確㤎された。

2) ペレット中の酸素量が间じとき，陵化鉄の種類に よる溶解速度の相違は小さく，溶涻があるときにはほと んど相違が認められない。

3) $\mathrm{FeO}$ を含有するペレットの溶鉄中への溶解のみ かけの活性化エネルギは一部を除いて $\mathrm{Fe}_{2} \mathrm{O}_{3}$ を含有す るペレットと同じの $33 \mathrm{kal} / \mathrm{mol}$ であつた. $\mathrm{Fe}_{3} \mathrm{O}_{4}$ を含 有するペレットの $10.9 \%$ の低温側では $33 \mathrm{kcal} / \mathrm{mol}$, $21.8 \%$ の高温側拈よび $43.5 \%$ では $21 \mathrm{kcal} / \mathrm{mol}$ のみ かけの活性化ェネルギが得られた。

4) $\mathrm{FeO}$ または $\mathrm{Fe}_{3} \mathrm{O}_{4}$ を含有する還元鉄ベレットい 溶鉄中への溶解速度は， $\mathrm{Fe}_{2} \mathrm{O}_{3}$ を含有するものと同じく 溶鉄の炭素量が 2.5-3.5\% において最大となつた。

5) 最大溶解速度を示す炭素量以下において, $\mathrm{FeO}$ を 含有するペレットの溶解速度は, $\mathrm{Fe}_{2} \mathrm{O}_{3}$ を含有するもの と同じく溶鉄の炭素量の約 2.4 乗に比例し, $\mathrm{Fe}_{3} \mathrm{O}_{4}$ を含 有するペレットでは約 1.9 乗に比例した。

6)逼元鉄ペレットの溶鉄中への溶解速度はペレット 重量が増加するにしたがつて増大した。

\section{交献}

1) 佐藤彰, 中川龍一, 占松史朗, 福汒章: 尾崎 太，笠原和男，福沃安光，三井達郎：鉄と鋼，64 (1978) 3, p. 385

2) 佐藤 彰, 笠原和罗, 中川能一, 古松史朗, 福沢 章, 尾崎 太, 岩井良衛, 福沢安光, 三井達郎: 鉄と鋼，65（1979）2，p. 195

3 ) 佐藤彰, 中川龍一, 吉松史朗, 福沢 章, 尾崎 太：鉄と鋼，65 (1979) 12, p. 1683 
4) T. E. DANGY: JISI, 169 (1951) 9, p. 17

5 ) D. R. MAcRae: J. Metals, 17 (1965) 12, p. 1391

6 ) G. W. Lloyd, D. R. Young, and L. A. Baker: Ironmaking and Steelmaking. 2(1975) 1, p. 49

7) $O$. Kubachewski and $E$. L. Evans: Metallur- gical Thermochemistry, (1958). [Pergamon Press, London]

8 ）溶鋼 - 溶滓部会報告：溶鉄・溶滓の物性值便覧 (日本鉄鋼協会編)，(1972)

9 ) $H$. Shenck, E. Steinmetz, and $M$. Gloz: Arch. Eisenhüttenw., 39 (1968) 1, p. 69 